\title{
Fostering Eco-Cultural Literacies for Social, Cultural and Ecological Justice: A Perspective From Aotearoa (New Zealand)
}

\author{
Jenny Ritchie ${ }^{1}$ (D)
}

Published online: 11 August 2017

(C) Springer Science+Business Media B.V. 2017

\begin{abstract}
Pedagogies that reflect the eco-cultural literacies of local Indigenous peoples have potential to foster young children's empathy for our planet as well as for other humans and for more-than-human kin such as mountains, rivers, forests, plants, fish, insects and animals. This article explores some ways in which early years educators can implement pedagogical strategies that encompass the eco-cultural literacies of local Indigenous peoples. These pedagogical strategies are illustrated through data gathered from children, teachers and families in two early childhood centres that participated in a wider study of early childhood care and education settings in Aotearoa (New Zealand). The data show how these pedagogical approaches can generate dispositions of respect and restraint with regard to use of resources whilst introducing children to traditional Indigenous sustainability practices. Eco-cultural literacies provide a counter-narrative to dominant discourses that perpetuate the exploitation of our planet and her resources whilst confining the focus of education to predetermined, narrow literacy and numeracy standards. In drawing upon ancient wisdoms, there are implications for how early childhood care and education settings internationally can engage in localised eco-cultural literacies that offer hope for sustainable futures.
\end{abstract}

Keywords Eco-cultural literacies $\cdot$ Indigenous $\cdot$ Early childhood $\cdot$ Aotearoa New Zealand · Māori

Résumé Les pédagogies qui reflètent les connaissances éco culturelles des peuples indigènes locaux ont le potentiel de favoriser l'empathie des jeunes enfants envers notre planète ainsi qu'envers les autres êtres humains et, au-delà de la famille humaine, envers les montagnes, les forêts, les rivières, les plantes, les poissons, les

Jenny Ritchie

jenny.ritchie@vuw.ac.nz

1 Te Puna Akopai - School of Education, Te Whare Wānanga o te Ūpoko o te Ika - Victoria University of Wellington, Kelburn Parade, Wellington, New Zealand 
insectes ou les animaux, par exemple. Cet article explore quelques moyens par lesquels les éducateurs de la jeune enfance pourraient mettre en œuvre des stratégies pédagogiques englobant les connaissances éco culturelles des peuples indigènes locaux. Ces stratégies pédagogiques sont illustrées par le biais de données collectées auprès d'enfants, d'enseignants et de familles de deux centres de la petite enfance qui ont participé à une plus grande étude sur les centres d'éducation et de garde de la petite enfance en Aotearoa (Nouvelle-Zélande). Les données montrent comment ces pédagogies peuvent engendrer des dispositions de respect et de retenue dans l'utilisation des ressources tout en exposant les enfants aux pratiques traditionnelles durables des peuples indigènes. Les connaissances éco culturelles offrent une alternative aux discours dominants qui prônent l'exploitation de notre planète et de ses ressources en limitant l'attention de l'éducation à des normes prédéterminées et étriquées de littératie et de numératie. S'appuyer sur les sagesses anciennes a des implications pour la manière dont les contextes d'éducation et de garde de la petite enfance peuvent s'engager internationalement dans des connaissances éco culturelles locales qui donnent espoir dans un avenir durable.

Resumen Las pedagogías que reflejan los conocimientos ecoculturales de grupos indígenas locales tienen potencial para fomentar la empatía de niños de corta edad hacía nuestro planeta, otros seres humanos y otras especies como plantas, peces, insectos y animales. Este artículo explora algunas de las formas en las que los educadores infantiles pueden implementar estrategias pedagógicas que incluyan conocimientos ecoculturales de grupos locales indígenas. Estas estrategias pedagógicas están ilustradas a través de los datos recopilados de niños, profesores y familiares en dos centros infantiles que participaron en un estudio más amplio sobre los marcos educativos y de atención infantil en Aotearoa (Nueva Zelanda). Los datos muestran cómo estos enfoques pedagógicos pueden generar disposiciones de respeto y restricción con respecto al uso de los recursos mientras introducen a los niños en las prácticas de sostenibilidad indígenas tradicionales. Los conocimientos ecoculturales proporcionan una contranarrativa a los discursos dominantes que perpetúan la explotación de nuestro planeta y sus recursos mientras limitan el enfoque de la educación a estándares de conocimiento matemático y alfabetización restringidos y predeterminados. Según la sabiduría milenaria, existen sugerencias sobre la forma en que los marcos educativos y de atención infantil pueden proporcionar internacionalmente conocimientos ecoculturales localizados que ofrezcan una esperanza para los futuros sostenibles.

\section{Introduction}

The world is changing - education must also change. Societies everywhere are undergoing deep transformation, and this calls for new forms of education to foster the competencies that societies and economies need, today and tomorrow. This means moving beyond literacy and numeracy, to focus on learning environments and on new approaches to learning for greater justice, social equity and global solidarity. Education must be about learning to live on 
a planet under pressure. It must be about cultural literacy, on the basis of respect and equal dignity, helping to weave together the social, economic and environmental dimensions of sustainable development. (Bokova, Foreword, UNESCO 2015, p. 3).

We are now entering the age of the Anthropocene, the era in which human-induced (Anthropogenic) changes are influencing our planet in a similar magnitude to previous significant epochs, such as that which led to the extinction of the dinosaurs (Dalby 2014). Scientific reports confirm that human activity is now endangering our planet's life support system (Intergovernmental Panel on Climate Change 2013; Rockström 2016). Furthermore, the well-being of humanity is dependent on the biodiversity that surrounds us, and this is rapidly being depleted through our actions (Lambertini 2016). This process of biodiversity loss is being impacted by not only climate change, but also by other human-caused pressures that cause habitat destruction and despoliation, such as unsustainable agricultural practices, fisheries exploitation, mining, pollution and nuclear contamination. Social, economic and ecological sustainability and justice are therefore interdependent causes, and the severity and urgency of the situation position these as a paramount educational concern (UNESCO Global Education Monitoring Project 2016).

This paper builds on a qualitative study conducted in Aotearoa (New Zealand) which is reported in full elsewhere (Ritchie et al. 2010). It involved teachers, children and families from ten different early childhood care and education settings and focussed on "caring for ourselves, others and the environment", whilst drawing on Māori perspectives. This article considers ways in which early years pedagogies implemented by committed, experienced teachers can foster eco-cultural literacies that resonate empathy and care for one another, including more-than-human kin. "More-than-human" is a phrase that deliberately re-positions the earth along with all the creatures (other than humans) that reside upon our planet as worthy of prime consideration (Abram 1996; Haraway 2015; Plumwood 1999, 2002). Such ecocultural literacies provide a counter-narrative to national and international discourses that narrowly define and confine educational goals to be focussed on narrow standards of literacy and numeracy (Moss 2015; Moss et al. 2016). Instead, it is proposed that eco-cultural literacies based in the ecological wisdoms of Indigenous ${ }^{1}$ peoples offer children opportunities to embrace dispositions that equip them for living in a sustainability-oriented future.

\section{Context}

Aotearoa (New Zealand) is a small country in the South Pacific with 4.7 million people, $15 \%$ of whom are Māori, the Indigenous peoples of this land. After 200 years of British colonisation, te reo Māori, the Māori language, is severely endangered. In the most recent (2013) New Zealand Census:

\footnotetext{
${ }^{1}$ The term 'Indigenous peoples' refers to those people who are the original human inhabitants of a place, and who have lived there over an extended period of time. The capitalisation of the word Indigenous honours this status.
} 
21.3 percent of all Māori reported that they could hold a conversation in Māori [language] about everyday things. This was a decrease from 23.7 percent in 2006 and 25.2 percent in 2001 . Of the 148,400 people (or 3.7 percent of the total New Zealand population) who could hold a conversation in Māori in 2013, 84.5 percent identified as Māori. (New Zealand Ministry of Social Development 2016)

This decline in the numbers of speakers is a serious concern, as Indigenous languages such as te reo Māori are repositories of vast cultural knowledges related to particular ecologies garnered through long histories of co-evolution within these (Flannery 2010; Gorenflo et al. 2012). These languages also encode specific ecosystem information such as critical habitat information and preferences, pollination and dispersal interactions, as well as human benefits such as health and medicinal properties (Kimmerer 2011).

Also endangered as a result of European colonisation of this land are a vast number of Indigenous plant and animal species. This is due to a range of factors such as habitat as wetlands and Indigenous forests having been converted to farmland and forestry, as well as the devastation to flora and fauna caused by introduced pests such as possums, rats, ferrets and stoats. This is now being further exacerbated by climate change impacts (see, for example, Royal Forest and Bird Protection Society of New Zealand, n.d.). Māori, like other Indigenous peoples, had developed codes and practices that enabled them to live within a deeply respectful, empathic paradigm of inter-relatedness and interconnectedness with Papatūānuku (Earth Mother) and Ranginui (Sky Father), the original parents, and with all the features, creatures, flora and fauna descended from them, including humans.

This cosmology affirms an ethic of cohabitation based in acknowledgement of "the interdependence between the human line of descent and the world around them" and the recognition that the "health and well-being of the earth and atmosphere are essential for a continuation of human health and well-being" (Durie 1997 p. 146). Enacting and sustaining this ethical obligation required an extensive knowledge and repertoire of rituals and practices, a particular eco-cultural literacy. According to Williams (2001):

Maori had an extensive whakapapa [genealogy] of all flora and fauna, thereby codifying the natural world in a fashion similar to modern biological classification systems [italics in original]... In particular, the taxonomy practised by Maori was a taxonomy which related life forms and phenomenon back to their place in the ecology. That is, matauranga Maori [Māori knowledge] is a system which codifies knowledge according to its relatedness to environmental and life issues, rather than to what things are in themselves. The incipient Tohunga [Spiritual Experts] were extensively tutored in whakapapa, and therefore understanding of the physical and environmental world and how to live in it. (Rutten et al. 2013, p. 16)

This complex eco-cultural literacy that was carefully taught in every generation to the future guardians of the tribe's spiritual knowledge is one enabling of living 
sustainably with and within the planetary resources and boundaries. It sits in stark contrast to the compartmentalised and hierarchical western worldview that underpins the distancing and exploitation of both Indigenous peoples and the planet, in denial of an ethics of cohabitation (Butler 2012).

\section{Eco-Cultural Literacies}

Literacy, like education, is not neutral, but a sociocultural, political construction:

Situating literacy in the context of the power structures of society and institutions raises important questions: Whose literacies are dominant? Why are some literacies marginalized? What should we teach our students? What exactly do we mean by we? The concept of literacy inevitably implies a focus on how human beings use symbols to construct and negotiate meaning. (Rutten et al. 2013, p. 445)

This paper argues for a broadening of the notion of "literacy" as currently mandated in early years' education in many countries, including New Zealand, where "national standards" for literacy and numeracy' have been imposed into the primary school education system (Thrupp 2014; Thrupp and Easter 2013). Whilst drawing upon the concept of "ecological literacy", which involves "a deeper transformation of the substance, process and scope of education" in response to the current ecological crisis (Orr 2005, p. x), the proposed notion of "eco-cultural literacies" also incorporates a Freirean view of literacy (Freire 1972). In this view, literacy is not only a means for comparatively disenfranchised citizens, including children, to reclaim power through naming their world (Freire 1972), but it also recognises that the specific ecological places that we inhabit have their own literacies to which we can become privy through empathic attunement and sustained relationships over time (Abram 1996, 2010). Historically, for traditional peoples the eco-literacy of observing, listening to, recognising and storying their specific ecological niches within the world has enabled humans to cohabit and co-evolve in situationally intertwined and responsive ways (Penetito 2009; Rose 2002; Sommerville 2007). However, the industrial/technocisation of modernist, western onto-epistemologies (i.e. integrated belief and knowledge systems) have served to alienate us from this dialogue with/in our ecological places, limiting and denying possibilities for ecocultural literacies. It has served the modernist project well to ignore the existence of eco-cultural literacies as upheld by traditional ecological knowledge systems. The exploitation of both Indigenous peoples and eco-systems has gone hand in hand. Eco-cultural literacies drawing upon long-standing local Indigenous knowledges offer a life-serving counter-narrative. Eco-cultural literacies are at the heart of place-based pedagogies that acknowledge local Indigenous knowledges and practices (Penetito 2009). 


\section{Re-Visibilising Eco-Cultural Literacies}

The world is constructed of the acts of each one of us

(Marta Navichoc Cotuc, as cited in Dayton and Rogoff 2013, p. 109)

Narratives are our sources of meaning and of the literacies that are socially and culturally reified. The stories we tell reflect our ethics, values and priorities (King 2005). They convey powerful cultural messages, yet it is often the stories of majority cultures that come to dominate, a hegemonic process that invisibilises the narratives of Indigenous peoples (Adichie 2009).

Dominant culture narratives perpetuate a sense of separation from nature, which is positioned as a resource to be exploited by humans, even within many contemporary sustainability narratives, as critiqued by an Indigenous Elder as follows:

This idea of sustainability sounds to me like the same old formula by which people simply continue to take from the earth. They just want to keep taking. You can't just take. Tell them, that among our people our concern is not what we can take from the land, but what we can give. (An Algonquin Elder, as explained to Carol Crowe, an Algonquin ecologist, as cited in Kimmerer 2011, p. 257)

Indigenous Elders are repositories of narratives that reflect knowledges accumulated over time, treasured and passed on, generation after generation, in order to ensure the ongoing cohabitation within their particular, specific ecological settings (Knudtson and Suzuki 1992; Ritchie 2014). These narratives have stood the test of time, being drawn from deeply attuned observation over many generations, of the interactive patterns of weather, climate, seasons, oceans, mountains, wetlands, rivers, soils, flora and fauna, by humans who saw their role as serving to respect and protect these more-than-human kin. Traditional ecological knowledges recognise our human dependence on Mother Earth. This is expressed through gratitude and respect for the sustenance that she provides and through the reciprocal obligation to care for her in return (Kimmerer 2011). Integral to Indigenous perspectives are spiritual rituals that resonate this respect and concern for the land, rivers, mountains and oceans.

Unfortunately, colonisation has severely impacted the capacity for these knowledges to be transferred and upheld. As Indigenous peoples' lands are colonised and converted to modern monocultures of agricultural mass productivity (Shiva 2012), simultaneously, the biodiversity and language diversity as well as the eco-literacies that emanate from these are obliterated (Gorenflo et al. 2012)

An example of deliberate and overt suppression of this process of intergenerational knowledge transmission can be seen in the New Zealand government's Suppression of Tohunga Act of 1907, an oft-cited example of colonialist oppression, symbolising "the subordination of mātauranga Māori (Māori knowledge) to European knowledge" (Waitangi Tribunal 2011, p. 607). Tōhunga are experts and leaders. The Act referred to spiritual experts who conducted traditional Māori 
healing practices, which often involved use of an extensive Indigenous pharmacology as well as spiritual rituals. Growing up in Aotearoa in the 1960s, I learnt very little about the flora and fauna of my country, let alone that there was an extensive Indigenous pharmacology related to our particular context that Māori had utilised extensively over many centuries (Riley 1994). Such was the invisibilisation of te ao Māori (Māori worldview) narratives that this Indigenous eco-cultural literacy was not accessible to New Zealand school children of my generation, nor has it been mandated for subsequent generations, the exception being for children who attend kura kaupapa Māori, schools that are grounded in te ao Māori (the Māori world) and teach via the medium of the Māori language.

As educators, it is important that we are very conscious and deliberate with regard to the messages conveyed in the literacies we model and promote. Early childhood care and education in Aotearoa have a strongly narrative approach to both pedagogy and assessment. One of the goals of the early childhood curriculum, Te Whäriki (New Zealand Ministry of Education 1996, 2007) is that children should "experience the stories and symbols of their own and other cultures" (New Zealand Ministry of Education 1996, p. 72).

The Te Whäriki curriculum in place at the time of the study required parallel recognition of the culture and language of the Indigenous Māori: "There should be a commitment to the recognition of Māori language_-stories, symbols, arts and crafts-in the programme" (New Zealand Ministry of Education 1996, p. 72). Furthermore, the document stated that there should be "a recognition of Māori ways of knowing and making sense of the world and of respecting and appreciating the natural environment" (p. 82). It also required teachers to "actively seek Māori contributions to decision-making" (p. 40), and that "Liaison with local tangata whenua" (people of the land-Indigenous people) and respect for Papatūānuku, the Earth Mother "should be promoted" (p. 54). Part B, the Māori text of the 1996 curriculum, contained extensive reference to the role of children as kaitiaki (guardians) of the whenua (land), and of its wairua and mauri (spiritual interconnectedness and life force).

\section{Fostering Empathy for Our Planet and Cohabitants}

Goal 4 of the recently promulgated United Nations' Sustainable Development Goals focuses on quality education (UNESCO Global Education Monitoring Project 2016). The aim of Goal 4.7 is that by 2030 all the world's nations ensure that:

All learners acquire the knowledge and skills needed to promote sustainable development, including, among others, through education for sustainable development and sustainable lifestyles, human rights, gender equality, promotion of a culture of peace and nonviolence, global citizenship and appreciation of cultural diversity. (UNESCO Global Education Monitoring Project 2016, p. 7)

A post-humanist critique of this goal would point to the invisibility of the morethan-human realm in this statement. Post-humanist theorising seeks to move the 
agenda beyond a focus that positions humans as central and predominant, instead seeing humans as living inter-dependently with and on the planet. Integral to the achievement of living sustainably within our finite planet is the cultivation of empathy and compassion for others, including our more-than-human cohabitants, and for the planet itself, its biosphere and atmosphere. This is increasingly salient as Anthropogenic impacts mean that the Earth's biosphere is now being supplanted by the exponential growth of the technosphere (Zalasiewicz et al. 2016).

In the remaining sections of this paper, two case studies of examples are drawn from a research project that explored ways in which early childhood care and education settings responded to a concern for "caring for ourselves, others and the environment", whilst incorporating te ao Māori (Māori worldview) perspectives into their pedagogical approaches (Ritchie et al. 2010). The intention is to illuminate possibilities for pedagogical re-narrativisation of Indigenous eco-literacies within white/mainstream early childhood care and education settings.

\section{Case Study 1: Generating Dispositions of Empathy and Restraint for Cohabiting on a Finite Planet at Richard Hudson Kindergarten}

During the period of the research project, the teachers of Richard Hudson Kindergarten in the city of Dunedin in the South Island, Te Wai Pounamu, thoughtfully employed a range of pedagogical approaches. They began by consulting with an Indigenous Elder and employing the narratives that he shared to generate empathy and concern for Papatūānuku, the Earth Mother, and Ranginui, the Sky Father. Further on, in the study they applied further te ao Māori constructs such as rāhui [prohibitions] to set in place a sense of collective responsibility in relation to constraints aimed at protection of resources.

Māori cosmology tells the story of the original parents, Papatūānuku and Ranginui, the Earth Mother and Sky Father, living in such close proximity that there were no light and insufficient space for their children. One of these, the deity TâneMahuta eventually physically forced his parents apart. He then proceeded to procreate, generating humans, trees, insects and animal life. In this genealogical understanding, humans are but junior siblings, part of a wider web of interrelatedness:

As people share a common lineage with the flora and fauna and therefore belong to the same extended family, the recognition of kinship rights and obligations is required. A Māori worldview establishes that all life forms are interconnected and interdependent so environmental practices must be underpinned by a code of ethics based on mutual respect, reciprocity and care. This position advocates for sustainable resource use and land development rather than one that is based on extractive methods that are harmful. (Tomlins-Jahnke and Forster 2015, p. 46)

When teachers at Richard Hudson Kindergarten introduced the children to the story of the separation of Papatūānuku and Ranginui, this resonated deeply with the children as demonstrated in their stories, artwork and photographic representations 
of these understandings. The teachers described, for example, artworks by two of the children:

Erin and Simon ${ }^{2}$ both showed an immediate understanding of the concept of Rakinui/Ranginui [Rakinui is Southern Māori dialect] and Papatūānuku. They both chose to represent their understandings through art work. Erin's picture was her identical representation of the poster that was used to teach the story at mat time, after the initial full story was told. She has correctly shown Papatūānuku lying down and the children between her and Rakinui/Ranginui up above. Simon's artwork is more abstract. He has interpreted the story as layers - the most dramatic being the dark layer between the sky and earth (the children). His picture was drawn after being taught about leaves turning to humus and then to soil and how it nourishes Papa [Papatūānuku]. Leaves from our kindergarten's trees were used to show the gradation of the decomposition.

Another child, Linda, wrote her own story to accompany her painting that reflected her empathy for the sorrow of Papatūānuku and Ranginui when their children forced them apart:

Rangi is at the top. He is really, really close to the children. You can't see the baby because he's in the ground with his mother. They pushed them apart. The Earth Mother wasn't close to Rangi anymore. So. So. So. So. Sad.

Polly was also concerned for the well-being of Papatūānuku and Ranginui. Her mother wrote a note to the teachers explaining her daughter's previous late arrival to kindergarten:

The other day we were a bit late for school, Polly wanted to pick up the rubbish around the neighbourhood. She said there was rubbish on the Earth Mother's Body (Papatuanuku). She is quite concerned about smoke going into Rangi the Sky father's lungs and it would be hard for him to breathe! We want to do a beach clean-up too.

This pedagogical approach of introducing Māori cosmological narratives, which are analogous to family relationships, serves not only to foster children's empathy for the earth and sky but "to generate obligations and responsibilities of people and their communities to ancestral landscapes" (Tomlins-Jahnke and Forster 2015, p. 47). Polly's mother's mentioning that her family was planning a beach clean-up is an example of early childhood care and education sustainability pedagogies generating "eco-waves" outward into the community (Duhn and Ritchie 2014).

Another pedagogical approach introduced at Richard Hudson Kindergarten was that of the Māori concept of rāhui, a "restriction or prohibition where something becomes tapu, or set apart from normal use" (Kawharu 2000, p. 357). Rāhui are integrally connected to the implementation of kaitiakitanga, the responsibility to exercise guardianship that ensures the well-being of the earth and her resources, the practice of which "weaves together ancestral, environmental and social threads of identity, purpose and practice" (Kawharu 2000, p. 357).

\footnotetext{
${ }^{2}$ Children's names have been changed.
} 
Rāhui were traditionally applied to a physical area by a tohunga, or spiritual expert who would perform a karakia or "incantation", "inducing presiding spiritual powers to intervene and render it tapu, and to offer protection and help the resource area to return to normal health" (Kawharu 2000, p. 357). Adele, one of the teachers at Richard Hudson Kindergarten, reported on how she had successfully introduced the practice of rāhui to the children:

It was while trawling through the Te Ara/New Zealand Encyclopedia site that I saw the heading 'Conservation Through Rāhui'. It interested me, and 'planted a seed of thought' in my mind. It talked about limits being placed on resources when they were scarce to ensure their continuation in the long term. It explained that the limits were localised, and entirely respected and adhered to.

When I heard the other teachers talking about the flowers from the front steps being picked, the idea in my head began to germinate. We had a parallel situation here at kindergarten-a localised shortage on a precious resource. I could teach the children about conservation through rāhui. This Māori conservation concept would be hard for children to understand without a practical application, or a real context. This was the perfect opportunity to teach it meaningfully, to plant a seed of understanding in their minds, as they develop their bicultural understandings of the necessity for such concepts. The flowers on the front steps had a rāhui placed on them to ensure they lasted, and flowers for the enjoyment and creativity of the children were sourced elsewhere. And it worked!

Recognising and respecting the limits and constraints of both planetary boundaries as well as local resources are the key to living sustainably on our planet. The Māori notion of rāhui is an Indigenous eco-cultural literacy that made sense within this kindergarten community. Enacting this practice offers children the opportunity to learn to respect and apply the Māori ethic of cohabitation that protects the more-than-human world. This is an ethic that involves ritual expression of respect for and obligation to the wider collective of both humans and the more-than-human world, in order to generate restraint within the individual, for the wider benefit of the collective (Williams 2009). Such restraint is a feature of collectivist societies yet not so salient in the western individualistic modernist paradigm. This lack of restraint is implicated in the plundering of the planet's natural resources and as such needs to be part of the transformative agenda of sustainability movements. Indigenous models for exercising a disposition of restraint are thus worthy of attention as educators devise pedagogical strategies for imbuing an ethics of cohabitation for sustainability.

\section{Case Study 2: Learning from Traditional Modes of Sustainable Food Gathering and Healing Practices at Hawera Kindergarten}

The teachers at another of the kindergartens in our study, Hawera Kindergarten, adopted a methodology that highlighted traditional seasonal Māori sustainability practices in tandem with their contemporary pedagogies. Hawera is a small rural, 
coastal Māori community in the North Island of Aotearoa, Te Ika a Māui, with a higher Māori population that that of the city of Dunedin. The teachers, two of whom were Māori, drew upon a traditional Māori maramataka, a calendar outlining traditional seasonal practices in line with the lunar cycles, positioning these practices alongside those which were happening at the kindergarten. For example in October, or Whiringa $\bar{a} \mathrm{Nuku}$, they provided explanations on their noticeboard for parents and families with regard to their programmes current focus of comparing traditional seasonal practices to the current work at kindergarten. Traditional practices taken from the maramataka for this time of year were described as follows:

\section{The earth has now become quite warm.}

\section{For Māori [traditionally], this meant...}

- Planting of crops began

- Crayfish, eel, inanga [whitebait] and freshwater fish were caught inland

- Tarakihi and gurnard fish were caught at sea

- The roots of the Tī tree were dug up for medicinal purposes

The teachers juxtaposed these traditional practices with alongside their pedagogical focus on gardening, food gathering, preparation and preservation, and rongoā Māori (Māori medicines). Via the noticeboard and newsletters sent home, they asked parents/whānau (extended families) to provide information regarding their home practices in relation to gardening, food preparation and preservation, and home remedies for ailments:

\section{For us, it means...}

\section{Finding out from our whanau...}

- Who has a garden? How do they prepare and look after their garden?

- Who "stores" food? Do they freeze food, preserve food (fruit, jam, etc.), dry their food? Who collects kai [food]? Do they go to the beach and gather shellfish? Do they go fishing? Collect mushrooms? Anything else?

- Who has "homemade" remedies for aches and pains?

- We really want to know about these things!!

With the intention of familiarising the children with traditional Māori uses of the healing properties of Indigenous plants, the teachers introduced the children to a picture book called “Koro's Medicine” (Drewery 2004), in which a grandfather (Koro) treats his grandson's injuries and ailments with traditional Māori remedies. They also asked the children about the remedies that were used by their families to treat common ailments. Next they supported the children to identify some of the Indigenous plants growing in the playground and learnt about some of their healing properties and other uses. They reported this as follows:

We used an illustrated book called 'Wai Rākau, essence of the forest Māori Herbal Remedies', about rongoā from native plants. The children took photos 
and were curious to know what they were for. While Harakeke [flax] was used for Tama's blisters [in the story 'Koro's Medicine'], it was also used to make kete [baskets], whāriki [mats] and kākahu [clothing].

Plants we found included Pohutukawa, T̄̄ Kōuka, Kōwhai, Kawakawa, Harakeke, Koromiko, Puawānanga, and Rahurahu.

We also looked at edible plants which included pūhā, and the vegetables in our gardens: carrots, peas, lettuce, tomato, parsley, coriander.

Joy [a Māori teacher] shared some personal experiences her Mum used, such as applying pūhā sap to warts.

The children had observed that at this time of year the kindergarten vegetable gardens were drying out and required more frequent watering. The teachers extended children's understandings further, making links to local Māori healers and traditional food gathering practices:

One of the things we noticed as we talked about Rongoā was it always referred back to kai, [food] the cultivation and gathering of it. So Joy shared a book with the children about local Taranaki people and their healing stories. This book was called, 'Matarakau. Ngā kōrero mō ngā rongoā o Taranaki. Healing stories of Taranaki' (Tito et al. 2007). She focused on one local Kuia [Woman Elder] who grew up at Rangatapu our local beach.

Kui [Kui is short for Kuia] Trish grew up at Rangatapu, Ohawe Beach. Life was simple and they were always well fed. The gathering and growing of kai by her parents and whānau was her rongoā. Their wellness as children was dependent on fresh air and food that had been either gathered from the sea or collected from the homegrown gardens. Kai was gathered and preserved. Everything was dried including dried whitebait and mussels. They made jams and pickles. She remembered her Kuia walking down the hill with a kete kai moana [seafood gathering basket] to gather kai. They wove their kete with harakeke that grew nearby. Kai was gathered daily. Karakia [spiritual incantation] was said before gathering kai. They learnt the sounds of the sea, the signs of the incoming tide and the swiftness of the sea against the rocks. This was time to leave, even if their kete were not filled enough. They also gathered driftwood for the home fires.

Whilst Kui Trish didn't have native bush around them, she acknowledged she has little knowledge about leaves used for rongoā. However, living at the beach provided all their rongoā.

In sharing these stories with the children, rongoā comes in many forms and one adapts to the environment they live in.

Healing, in this traditional Māori view, is a gift of nourishment that one receives from living in attunement with the land, oceans and harvests. As with the work at Richard Hudson Kindergarten, the Māori narratives that were shared with children 
resonated deeply with them. Many of the children shared their own experiences related to going to the seaside and to gardening at home:

[Teacher]: What kai comes from the sea?

Seaweed, sharks, fish, mussels, crabs, paua [abalone]

We had some paua—we just went and got some, and crabs. (JG)

Grandad likes the yucky things_-green and slimy—and he opens them! (LE)

Grandad grows tomatoes and he eats them and cooks them. (GC)

Our garden looked dry so I watered it. We put scraps what the pigs eat in a box... tip them out, put them in our garden to make our garden grow! (your garden must be magnificent!) It is!! (MP)

There's no mermaids! My Nan found a fish tail, like a mermaid. (SJ)

My dad puts the boat, Dad goes out (SS)

My dad goes to the tide... he gets fish... and um... chips and sauce

Parents and whānau also responded to the request for information about their food gathering practices:

My Nanny B and T have a garden... they grow tomatoes and spuds...they take the weeds out so they don't make the spuds die!... They also grow mint and silver beet so we can mash them into our kai. My Koro and my Nanny go to the beach and get kai from there. My Koro dives in the sea and eels under the rocks to find pauas...sometimes kinas and mussels. Koro takes me fishing but we haven't caught a fish yet!. We go to catch eels at night in the rivers, with a long knife-I have catch one! When I have a headache my Nanny and Mum tell me to lay down where it's nice and quiet so it goes away... and it does! (KG and his whanau)

We have a garden...we water our plants so they can have a drink... we dig out our weeds and trim our plants. We stew our apples and plums when we have some...sometimes we freeze it so we can have some another day. (GC and her whanau)

The above excerpts from the Hawera Kindergarten teachers' reports for the project demonstrate many of the ways in which their pedagogical approaches introduced eco-cultural literacies reflecting Māori worldviews pertaining to sustaining wellbeing. These included traditional practices of gardening, gathering seafood and utilising Indigenous pharmacological remedies. The teachers also shared some of their reflections on the project, as to their pedagogical strategies and children's responses to these:

Keeping it simple for the children worked well, making it real...

Concepts about gardening were things that were familiar to them 
I liked how we linked to the Māori calendar, for our planting... and children took ownership of the gardening from day one.

We learnt about the knowledge they already had about medicines, composting...

Talking to families_-what's important to them was really fascinating.

We introduced new language through exploring the concepts. Some was 'outside' of their world but done in a way that they knew it was important... we had their trust and acceptance.

Grasping concepts of rongoā through sharing 'Koro's Medicine'...you don't have to go to the bush to see them (plants), they are in our environment.

Children came at different times and in different ways, to contribute to the care of the environment...

Our level (of knowledge and learning) was the children's level... we discovered so much together!

They watched, they listened, they contributed... they made links to their own world-making their own connections. Children took what they could make sense of, what was useful to them and their whānau.

The teachers were enthusiastic about the co-constructive, collaborative learning process they had instigated, and the resulting engagement of children and families/ whanau in the project focus. In involving the families in the sustainability agenda, they also learnt more about families' different sustainability practices and healing traditions as well as extending their own knowledge of local traditional healing and food gathering practices.

\section{Implications for Early Childhood Research, Policy, and Practice}

The work of early childhood care and education is deeply ethical practice. At this time of increasing recognition of Anthropogenic impacts on our planet, teachers have the potential to be at the forefront of cultivating social transformation towards sustainable ways of living (UNESCO 2012). At the heart of this work lie a commitment and intentionality derived from a consciousness regarding our work as educators. In informing our research, policy and practice, we can learn much from the wisdom of Indigenous peoples whose paradigms of spiritually embedded relational reciprocity with the land, rivers, oceans, plants and animals offer hope for sustaining life into the future.

This article has illustrated some examples of pedagogical strategies employed by kindergarten teachers in Aotearoa which fostered young children's empathy for the planet, generated dispositions of restraint, and cultivated knowledge and respect for Indigenous food gathering and healing practices. As educators, it is now our role to decisively contribute to making the Anthropocene "as short/thin as possible" (Haraway 2015, p. 160) by pedagogically reframing ways of living so that the children and families with whom we engage become collaborative cohabiters of our planet. 
Acknowledgements The author gratefully acknowledges Project co-directors Cheryl Rau, Iris Duhn and Janita Craw; teacher co-researchers; the children and families who participated in the project; and our funders, the New Zealand Teaching and Learning Research Initiative (TLRI).

\section{References}

Abram, D. (1996). The spell of the sensuous. Perception and language in a more-than-human world. New York: Vintage Books.

Abram, D. (2010). Becoming animal. An earthly cosmology. New York: Vintage.

Adichie, C. N. (2009). The danger of a single story: TED global. Retrieved from https://www.ted.com/ talks/chimamanda_adichie_the_danger_of_a_single_story?language=en.

Butler, J. (2012). Precarious life, vulnerability and the ethics of cohabitation. The Journal of Speculative Philosophy, 26(2), 134-151.

Dalby, S. (2014). Environmental geopolitics in the twenty-first century. Alternatives: Global, Local, Political, 39(1), 3-16.

Dayton, A., \& Rogoff, B. (2013). 'On Being Indigenous' as a process. Human Development, 56, $106-112$.

Drewery, M. (2004). Koro's medicine. Wellington: Huia.

Duhn, I., \& Ritchie, J. (2014). Making "eco-waves": Early childhood care and education sustainability practices in Aotearoa New Zealand. Children, Youth and Environments, 24(2), 123-145.

Durie, A. (1997). Te Aka Matua. Keeping a Māori Identity. In P. Te Whāiti, M. McCarthy, \& A. Durie (Eds.), Mai i Rangiātea. Māori Wellbeing and Development (pp. 142-162). Auckland: Auckland University Press with Bridget Williams Books.

Flannery, T. (2010). Here on earth. A natural history of the planet. Toronto: HarperCollins.

Freire, P. (1972). Pedagogy of the oppressed. London: Penguin.

Gorenflo, L. J., Romaine, S., Mittermeier, R., A., \& Walker-Painemilla, K. (2012). Co-occurrence of linguistic and biological diversity in biodiversity hotspots and high biodiversity wilderness areas. In Proceedings of the National Academy of Sciences of the United States of America, (Vol. 109(21), pp. 8032-8037). Retrieved from http://www.pnas.org/content/8109/8021/8032.

Haraway, D. (2015). Anthropocene, Capitalocene, Plantationocene, Chthulucene: Making kin. Environmental Humanities, 6, 159-165.

Intergovernmental Panel on Climate Change. (2013). Working group I contribution to the IPCC fifth assessment report climate change 2013: The physical science basis. Summary for policymakers: Intergovernmental Panel on Climate Change. Retrieved from http://www.ipcc.ch/index.htm\#. Uk4dnVP4WSo.

Kawharu, M. (2000). Kaitiakitanga: A Maori anthropological perspective of the Maori socioenvironmental ethic of resource management. The Journal of the Polynesian Society, 109(4), 349-370.

Kimmerer, R. (2011). Restoration and reciprocity: The contributions of traditional ecological knowledge. In D. Egan, E. E. Hjerpe, \& A. Jesse (Eds.), Human dimensions of ecological restoration integrating science, nature, and culture (pp. 257-276). Washington, DC: Island Press.

King, T. (2005). The truth about stories. A native narrative. Minneapolis: University of Minnesota Press.

Knudtson, P., \& Suzuki, D. (1992). Wisdom of the Elders. Sydney: Allen and Unwin.

Lambertini, M. (2016). Living on the edge. In World wildlife fund, living planet report 2016. Risk and resilience in a new era. Gland, Switzerland. Retrieved from http://wwf.panda.org/about_our_earth/ all_publications/lpr_2016/.

Moss, P. (2015). There are alternatives! Contestation and hope in early childhood education. Global Studies of Childhood, 5(3), 226-238.

Moss, P., Dahlberg, G., Grieshaber, S., Mantovani, S., May, H., Pence, A., et al. (2016). The organisation for economic co-operation and development's international early learning study: Opening for debate and contestation. Contemporary Issues in Early Childhood, 17(3), 343-351.

New Zealand Ministry of Education. (1996). Te Whāriki. He whāriki mātauranga mō ngā mokopuna o Aotearoa: Early childhood curriculum. Wellington: Learning Media. Retrieved from http://www. education.govt.nz/early-childhood/teaching-and-learning/ece-curriculum/te-whariki/.

New Zealand Ministry of Social Development (2016). The social report 2016-Te pürongo oranga tangata. Retrieved from http://socialreport.msd.govt.nz/cultural-identity/maori-language-speakers. html. 
Orr, D. W. (2005). Foreword. In M. K. Stone \& Z. Barlow (Eds.), Ecological literacy. Educating our children for a sustainable world (pp. ix-xi). San Francisco: Sierra Club Books.

Penetito, W. (2009). Place-based education: Catering for curriculum, culture and community. New Zealand Annual Review of Education, 18(2008), 5-29.

Plumwood, V. (1999). Ecological ethics from rights to recognition. In N. Low (Ed.), Global ethics and environment (pp. 188-212). New York: Routledge.

Plumwood, V. (2002). Environmental culture. The ecological crisis of reason. London and New York: Routledge.

Riley, M. (1994). Maori healing and herbal-New Zealand ethnobotanical sourcebook. Paraparaumu, NZ: Viking Sevenseas.

Ritchie, J. (2014). Learning from the wisdom of elders. In J. Davis \& S. Elliot (Eds.), Research in early childhood education for sustainability: International perspectives and provocations (pp. 49-60). Abingdon, OX: Routledge.

Ritchie, J., Duhn, I., Rau, C., and Craw, J. (2010). Titiro Whakamuri, Hoki Whakamua. We are the future, the present and the past: caring for self, others and the environment in early years' teaching and learning. In Final report for the teaching and learning research initiative. Wellington: Teaching and Learning Research Initiative. Retrieved from http://www.tlri.org.nz/tlri-research/researchcompleted/ece-sector/titiro-whakamuri-hoki-whakamua-we-are-future-present-and.

Rockstrom, J. (2016). A resilient earth for future generations. In World wildlife fund, living planet report 2016. Risk and resilience in a new era. Gland, Switzerland: International. Retrieved from http:// wwf.panda.org/about_our_earth/all_publications/lpr_2016/.

Rose, D. B. (2002). Dialogue with place: Toward an ecological body. Journal of Narrative Theory, 32(3), 311-325.

Royal Forest and Bird Protection Society of New Zealand. (n.d.). Climate change. Retrieved from: http:// www.forestandbird.org.nz/saving-our-environment/climate-change.

Rutten, K., Rodman, G. B., Wright, H. K., \& Soetaert, R. (2013). Cultural studies and critical literacies. International Journal of Cultural Studies, 16(5), 443-456.

Shiva, V. (2012). Monocultures of the mind. Perspectives on biodiversity and biotechnology. Penang: Third World Network.

Sommerville, M. (2007). Place literacies. Australian Journal of Literacy and Language, 30(2), 149-164.

Thrupp, M. (2014). At the eye of the storm: Researching schools and their communities enacting National Standards. New Zealand Journal of Educational Studies, 49(1), 6-20.

Thrupp, M., \& Easter, A. (2013). 'Tell me about your school': Researching local responses to New Zealand's National Standards policy. Assessment Matters, 5, 94-115.

Tito, J., Pihama, L., Reinfeld, M., \& Singer, N. (Eds.). (2007). Matarakau. Ngā kōrero mō ngā rongoāo Taranaki. Healing stories of Taranaki. Taranaki: Karangaora.

Tomlins-Jahnke, H., \& Forster, M. (2015). Waewaetakamiria. Caress the Land with Our Footsteps. In E. S. Huaman \& B. Sriraman (Eds.), Indigenous innovation (pp. 43-55). Rotterdam: Sense.

UNESCO. (2015). Rethinking education. Towards a global common good? Paris: UNESCO. Retrieved from http://www.unesco.org/new/en/education/themes/leading-the-international-agenda/rethinkingeducation/.

UNESCO Global Education Monitoring Project. (2016). Education for people and planet: Creating sustainable futures for all. Paris: UNESCO.

United Nations Educational Scientific and Cultural Organization (UNESCO). (2012). Shaping the education of tomorrow. 2012 Report on the UN Decade of Education for Sustainable Development. (Full report). Paris: UNESCO. Retrieved from http://www.desd.org/UNESCO\%20report.pdf.

Waitangi Tribunal. (2011). Ko Aotearoa tēnei. A report into claims concerning New Zealand law and policy affecting Māori culture and identity. Wai 262. Te taumata tuarua, (Vol. 2). Wellington: Waitangi Tribunal. Retrieved from http://www.justice.govt.nz/tribunals/waitangi-tribunal.

Williams, D. (2001). Matauranga Maori and taonga. The nature and extent of Treaty rights held by Iwi and Нари in Indigenous flora and fauna, cultural heritage objects, valued traditional knowledge. Wellington: Waitangi Tribunal.

Williams, J. (2009). "O ye of little faith": Traditional knowledge and western science. Journal of the Royal Society of New Zealand, 39(4), 167-169.

Zalasiewicz, J., Williams, M., Waters, C. N., Barnosky, A. D., Palmesino, J., Rönnskog, A.-S., et al. (2016). Scale and diversity of the physical technosphere: A geological perspective. The Anthropocene Review. doi:10.1177/2053019616677743. 